\title{
Effect of slaughter weight on the quality of Nile tilapia fillets
}

\author{
Carlos Adriano Rocha Silva Morais ${ }^{\mathrm{a}}$, Thaís Pacheco Santana ${ }^{\mathrm{a}}$, Camilo Azevedo Santos ${ }^{\mathrm{a}}$, \\ Rodrigo Augusto Cortez Passetti ${ }^{\mathrm{b}}$, José Fernando Bibiano Melo ${ }^{\mathrm{c}}$, \\ Francisco de Assis Fonseca de Macedo ${ }^{\mathrm{a}, \mathrm{b}}$, Jodnes Sobreira Vieira ${ }^{\mathrm{a}}$, Alfredo Jorge Costa Teixeira ${ }^{\mathrm{d}}$, \\ Ana Paula Del Vesco ${ }^{\text {a,* }}$ \\ a Animal Science Postgraduate Program, Universidade Federal de Sergipe, São Cristóvão, Brazil \\ ${ }^{\mathrm{b}}$ Animal Science Postgraduate Program, Universidade Estadual de Maringá, Maringá, Brazil \\ ${ }^{\mathrm{c}}$ Animal Science Department, Universidade Federal do Vale do São Francisco, Petrolina, Brazil \\ d Animal Science Department, Instituto Politécnico de Bragança, Bragança, Portugal
}

\section{A R T I C L E I N F O}

\section{Keywords:}

Calpain expression

Calpastatin expression

Oreochromis niloticus

Meat quality

Ryanodine receptors

\begin{abstract}
A B S T R A C T
The objective of this work was to evaluate the influence of slaughter weight on the expression of calpastatin, $\mathrm{m}$ calpain and the RyR3 gene, and on the chemical composition, morphometric measurements, fillet yield and sensorial characteristics of Nile tilapia fillets. In the experiment, 90 Nile tilapia were divided into three experimental treatments regarding slaughter weight $(n=30)$ : in treatment 1 , tilapia aged 140 days were slaughtered with an average body weight of $665 \pm 85 \mathrm{~g}$; in treatment 2 , the animals were slaughtered at 182 days and weighed $1000 \pm 177 \mathrm{~g}$; and in treatment 3, they were slaughtered at 238 days and weighed $1325 \pm 167 \mathrm{~g}$. There was no significant difference $(P>.05)$ between the treatments for the chemical composition and fillet yield. Fillets of tilapia slaughtered with a weight of $665 \mathrm{~g}$ presented higher expression of mcalpain and lower expression of calpastatin gene, lower $\mathrm{pH}$ values of the thawed fillet, lower drip and thawing loss, and lower shear force than animals slaughtered with the highest evaluated weight. Tilapias slaughtered at $665 \mathrm{~g}$ also presented higher flavor and general acceptance. These results show that slaughter weight may influence important aspects of the quality of Nile tilapia fillets and that the slaughter of Nile tilapia with a body weight of $665 \mathrm{~g}$ allows fillets that serve the consumer market to be obtained.
\end{abstract}

\section{Introduction}

The world fish production in 2016 was about 171 million tonnes, equivalent to 362 billion dollars. Nile tilapia represented $8 \%$ of total of finfish produced in world aquaculture in 2016, and together with freshwater species, tilapias are expected to represent about $62 \%$ of total world aquaculture production in 2030 (FAO, 2018). Tilapia presents several advantageous characteristics that allow success in the production process, such as tolerance to high density rates, rusticity, success in polycultures, and ability to accept low-cost diets (FAO, 2011; Fitzsimmons et al., 2011). Besides that, the characteristics of the animal such as white meat, firm texture, delicate flavor and the absence of intramuscular spines attract the consumer preference (Souza and Maranhão, 2001).

Fish meat is rich in high quality protein, essential amino acids, essential fats (omega-3), vitamins (D, A and B) and minerals such as calcium, iodine, zinc, and selenium. However, despite its high nutritional value, because it has fragile and easily degraded muscle tissue, fish meat is one of the most perishable and vulnerable to handling and processing (Cheng et al., 2015). The quality of fish meat may be influenced by intrinsic factors such as race, age and gender (Huff-Lonergan et al., 1995; Horcada et al., 1998), and by a number of environmental factors, such as slaughter conditions for example (Kristoffersen et al., 2006). Thus, changes in the appearance, texture, and chemical composition of meat can be observed under unfavorable environmental conditions (Castro et al., 2017).

There have been few studies dealing with the quality of tilapia meat (Kayan et al., 2015; Mohamed et al., 2016). From the consumer perspective, the quality of the meat can be subjective, varying between people, societies and cultures. In this way, a major challenge faced by the meat industry is obtaining information about the production process that guarantees the supply of qualified product (Damez and Clerjon, 2008).

Around the world, tilapia fillets represent the preference in the form

\footnotetext{
* Corresponding author at: Universidade Federal de Sergipe - Av. Marechal Rondon, Jardim Roza Elze, São Cristóvão, Sergipe 49100-000, Brazil.

E-mail address: apaulavesco@gmail.com (A.P. Del Vesco).
} 
of meat consumption for this species (Boscolo and Feiden, 2007). The producers of Nile tilapia in the European market are paid according to the fillet weight and their characteristics are truly important for the commercialization process (Rutten et al., 2005). The requirement for the weight of fillets sold worldwide is directly linked to the consumer's eating habits: in the United States of America and Brazil, European Union, and China, tilapias are slaughtered with average weights of 600 , 800 and $1200 \mathrm{~g}$, respectively (Department of Fisheries, 2009).

As the characteristics related to fish meat quality are complex and influenced by several factors that can determine the degree of freshness and acceptance of the product in the market, and considering the different demands of the consumer market, this work aims to evaluate the effect of slaughter weight of Nile tilapia on physical-chemical and sensory characteristics that are directly related to the quality of their meat.

\section{Material and methods}

\subsection{Animals and experimental design}

In this experiment, 90 Nile tilapia (Oreochromis niloticus) were evaluated with three different slaughter weights. All of the fishes were acquired from Sobradinho Fish Breeders Association, Sobradinho, Bahia, Brazil at the same time and with the same physiological condition with exception of age. Until the moment of acquisition, all the animals were raised under the same conditions in a net tanks system, with a volume of $2 \mathrm{~m}^{3}$ and 450 fish per tank. The water-quality parameters remained within the optimal comfort range of the species according to Kubitza (2000): dissolved oxygen $>5 \mathrm{~g} / \mathrm{l}, \mathrm{pH}=7$; temperature of $29^{\circ} \mathrm{C}$, and ammonia $\mathrm{NH} 3<1 \mathrm{mg} / \mathrm{l}$. All the tilapias were fed with commercial feed that was adequate to meet the nutritional requirements for each phase of the farming and had 55,32 and $28 \%$ of crude protein at fingerling, juvenile and termination phase, respectively (TOTAL AQUOS, Três Corações, MG, Brazil).

Each of the three experimental groups related to slaughter weight was composed of 30 specimens. In treatment 1, tilapia aged 140 days presented with a body weight of $665 \pm 85 \mathrm{~g}$ at slaughter; in treatment 2 , the animals were slaughtered at 182 days weighing $1000 \pm 177 \mathrm{~g}$, and in treatment 3 , animals were slaughtered at 238 days with a weight of $1325 \pm 167 \mathrm{~g}$.

Tilapias from all the three experimental groups were transported in boxes for live fish (Marine Equipment, SC, Brazil) from the tank to the laboratory. Before slaughter, the animals were divided into nine subgroups of 10 individuals per box, respecting the treatments defined above. These remained for $24 \mathrm{~h}$ in a closed recirculation system, composed of nine 10001 polyethylene boxes with a biofilter and artificial oxygenation until the moment of slaughter. This time was used to reduce the effect of stress caused by transportation. All of the animals were slaughtered by concussion. The same procedures were applied for all three groups during the entire experiment.

\subsection{Morphometric measurements and fillet yield}

The following morphometric measures were evaluated according to Pires et al. (2011): weight in grams, total length (TL), standard length (SL), head length (HL), body height (BH) and body width (BW) in centimeters.

To obtain the fillet, the skin of the animals was removed manually with a knife and pliers, and filleting was carried out in sequence. After filleting, the height (FH) and length (FL) of fillets were measured in centimeters, and weight was measured in grams. The fillet yield was calculated as a percentage according to the formula described by Costa et al. (2014): Yield of fillet (\%) = (fillet weight) / (total weight) $\times 100$.

The loin eye area (LEA) was measured using an A4 transparency slide and black permanent marker pen according to the pig carcass evaluation methodology standardized by the Brazilian Association of
Pig Breeders (ABCS, 1973). From the transparencies, the Image ${ }^{\circledast}$ IJ1.46r software was used to obtain the dimensions of the loin, length and height of the eye area as described by Teixeira et al. (2006).

\subsection{Physical characteristics}

Immediately after slaughter, the $\mathrm{pH}$ of the fresh fillet (pHFF) was measured using a Hanna HI99163 meat pH meter and piston with a penetration spit.

After that, the fillets were washed with running drinking water, packed in vacuum sealer bags $(30 \times 25 \mathrm{~cm}, 100 \mu \mathrm{m}$, Selovac 200 S, São Paulo, Brazil) and frozen in a freezer at $-18{ }^{\circ} \mathrm{C}$. For the measurement of $\mathrm{pH}$ of the thawed fillet and the color parameters, the fillets were thawed in refrigerator for $24 \mathrm{~h}$ at $4{ }^{\circ} \mathrm{C}$, separated and identified according to slaughter weight.

The $\mathrm{pH}$ evaluation was performed as described above, and color analyses involved two distinct points of the fillet $(1 ; 2)$ being measured for each color muscle fiber, white (B) and red (V). The evaluations were carried out using color read equipment (CR-10, Japan), and the parameters evaluated were $\mathrm{L}^{*}$ : luminosity; $\mathrm{a}^{*}$ : red-green component; and $\mathrm{b}^{*}$ : yellow-blue component (Minolta, 1998).

In order to obtain the values of water loss by thawing, the frozen samples were weighed in a digital analytical balance (initial weight) and then samples were weighed again after thawing (final weight). Thawing loss results were obtained by calculating the difference between the initial and final weights. Thawing occurred in a refrigerator at $4{ }^{\circ} \mathrm{C}$ for $24 \mathrm{~h}$. During this time, the samples were kept in a clean and sterile tray.

For drip loss (DL) analyses, raw fillet samples were weighed in natura (initial weight), after which the samples were placed in net-type bags and sealed in permanent plastic bags for $48 \mathrm{~h}$ in a refrigerator at $4{ }^{\circ} \mathrm{C}$. Following that time, they were again weighed (final weight). Drip loss was calculated using the formula described by Ramos and Gomide (2007): DL $=$ [(Initial weight- final weight) / Initial weight $]$ x100.

The evaluation of shear force was performed using the Brookfield texturometer CT3 (Texture Technologies 15 Corp., UK) fitted with a Warner-Bratzler blade. The speed used was $2 \mathrm{~mm} / \mathrm{s}$, the target distance was $30 \mathrm{~mm}$ and the force used was $10 \mathrm{~g}$. For evaluation, samples of $3.0 \mathrm{~cm}$ in height $\times 2.5 \mathrm{~cm}$ in width and $2.5 \mathrm{~cm}$ in length were taken from the dorsal area of the fillet. The results were expressed in $\mathrm{Kg}$.

\subsection{Chemical analysis}

Analyses of the chemical composition of fillets were carried out on samples of ten fillets from each slaughter weight $(n=10)$. For these analyses, half of each fillet was used. After thawing, the samples were ground individually in an electric mixer respecting the defined treatments. The samples were used to determine moisture (\%), dry matter (\%) and ash (\%), and crude protein (\%) according to AOAC (1998). Total lipid (\%) was determined according to Bligh and Dyer (1959).

\subsection{Sensory analysis}

For sensory analysis, 10 fillets of each treatment were thawed at $4{ }^{\circ} \mathrm{C}$ for $24 \mathrm{~h}$, separated, immersed in $1 \%$ saline solution and roasted with constant temperature monitoring through a spit-type thermometer until reaching the internal temperature of $70{ }^{\circ} \mathrm{C}$. The samples were divided into $2 \times 2 \mathrm{~cm}$ sizes, packed in aluminum foil identified with random numbers, and kept in an oven at $60{ }^{\circ} \mathrm{C}$.

The samples were given to 80 untrained tasters who then assessed their color, odor, texture, flavor, juiciness, and general appearance. During the test, the tasters received all samples simultaneously (three treatments), and were instructed to assess each sample individually. The tasters were instructed to use water and water-and-salt wafers to remove any residual flavor from the mouth between the samples.

A $10 \mathrm{~cm}$ scale was used, with unnumbered intervals, representing 
extremes: minimum (absence of sensation) and maximum (extremely intense sensation). The results were measured using a millimeter ruler to indicate the point corresponding to the intensity of their different sensations according to Rodrigues and Teixeira (2009). Each attribute ranged from zero (minimum intensity) to 10 (maximum intensity).

\subsection{Gene expression}

For gene expression analyses, white muscle samples were collected from five fish per treatment. The samples were stored in RNAlater ${ }^{\circledast}$ solution (Invitrogen, Carlsbad, CA, USA) at $-20{ }^{\circ} \mathrm{C}$ until total RNA was extracted. Total RNA was extracted using Trizol ${ }^{\circledR}$ (Invitrogen) according to the manufacturer's instructions $(1 \mathrm{ml} / 100 \mathrm{mg}$ tissue). The total RNA concentration was measured using a spectrophotometer at a wavelength of $260 \mathrm{~nm}$. RNA integrity was analyzed by $1 \%$ agarose gel electrophoresis followed by staining with ethidium bromide $(10 \mathrm{mg} / \mathrm{ml})$, and visualization under UV light. The RNA samples were treated with DNase I (Invitrogen) according to the manufacturer's instructions to remove any potential genomic DNA contamination.

The SuperScript ${ }^{\mathrm{TM}}$ III First-Strand Synthesis Super Mix kit (Invitrogen Corporation, Brazil) was used to synthesize cDNA from $1 \mu \mathrm{g}$ DNasetreated total RNA, according to the manufacturer's instructions. The cDNA concentration was measured using a spectrophotometer at a wavelength of $260 \mathrm{~nm}$. The cDNA samples were diluted to $40 \mathrm{ng} / \mu \mathrm{l}$ and stored at $-20{ }^{\circ} \mathrm{C}$ until further use as the template in the amplification reaction. Real-time PCR reactions were performed using the fluorescent SYBR Green dye (SYBR ${ }^{\circledast}$ Green PCR Master Mix, Applied Biosystems, USA). The amplification reaction consisted of $5 \mu \mathrm{l}$ diluted cDNA, $0.5 \mu \mathrm{l}$ each primer (forward and reverse) at a concentration of $10 \mu \mathrm{M}$ (final concentration: $200 \mathrm{nM}$ ), $12.5 \mu \mathrm{l}$ SYBR $^{\circledR}$ Green PCR Master Mix, and water to make up a total volume of $25 \mu$ l. To measure the efficiency of each primer/gene set, a series of $25 \mu \mathrm{l}$ reactions was performed as described above, using $5 \mu \mathrm{l}$ of a serial dilution of pooled cDNA as the template. The thermal cycling parameters for all genes were as follows: hot-start at $95{ }^{\circ} \mathrm{C}$ for $10 \mathrm{~min}$, followed by 40 cycles of denaturation at $95{ }^{\circ} \mathrm{C}$ for $15 \mathrm{~s}$ and annealing/extension at $60{ }^{\circ} \mathrm{C}$ for $1 \mathrm{~min}$, and ending with a melt curve from 65 to $95{ }^{\circ} \mathrm{C}$.

The primers utilized for the amplification of gene expression levels of calpastatin, m-calpain, and ryanodine receptor 3 (RyR3) were designed based on gene sequences deposited at www.ncbi.nlm.nih. gov (accession numbers XM_005450336.3, XM_019359456.1, and XM_019349095.1, respectively) using the site www.idtdna.com. ßActin was employed as the housekeeping gene. The amplification efficiency of $ß$-actin was similar to that of the target genes (Table 1). All of the analyses were performed in duplicate.

Amplification efficiencies (90-110\%) were similar for the genes of interest. Analysis of dissociation curves did not reveal any nonspecific PCR products, such as the formation of primer dimers,

Table 1

Primer sequences used for quantitative real-time polymerase chain reaction.

\begin{tabular}{|c|c|c|}
\hline Gene & Amplicon (bp) ${ }^{\mathrm{a}}$ & Primer sequence $\left(5^{\prime}-3^{\prime}\right)$ \\
\hline \multirow[t]{2}{*}{ CAST $^{\mathrm{b}}$} & 133 & AAGGTCAGAAGTGTGGAGAAAG \\
\hline & & TTTAGGGACATCCACAGGTTTAG \\
\hline \multirow[t]{2}{*}{$m-C A L P$} & 123 & GACGCAGGTTTCACTCTCAATA \\
\hline & & GAACATCATCTCCAGCСTCATC \\
\hline \multirow[t]{2}{*}{ RyR3 } & 140 & TGTTTCATCTGTGGGATCGG \\
\hline & & GTGTGCTCTGTCTCTCCTTG \\
\hline \multirow[t]{2}{*}{$\beta$-actin } & 217 & TGGTGGGTATGGGTCAGAAAG \\
\hline & & CTGTTGGCTTTGGGGTTCA \\
\hline
\end{tabular}

\footnotetext{
a Amplicon size in base pairs.

b Calpastatin (CAST), m-calpain catalytic subunit (m-CALP), ryanodine receptor 3 (RyR3).
}

demonstrating the reliability of the data for estimating mRNA expression of the examined genes. The endogenous control, $\beta$-actin, did not show any significant differences between treatments, confirming its suitability as a control.

\subsection{Statistical analyses}

The $2^{-\Delta \mathrm{CT}}$ method (Livak and Schmittgen, 2001) was utilized to analyze the relative change in expression of the examined genes. The Shapiro-Wilk test was applied to assess the normality of the data. The data were analyzed by one-way ANOVA. Where statistical significance was obtained, means were compared using Tukey's test $(P<.05)$ (SAS Version 9.0, SAS Inst. Inc., Cary, NC, USA). The results were presented as the mean and standard error.

\section{Results}

\subsection{Morphometric measures}

As expected, fish that were slaughtered with higher weights presented higher total length, standard length, head length, body width, body height, fillet weight, fillet height, and fillet length. We also observed treatment effects on loin eye area height (LEAH), loin eye area length (LEAL) and loin eye area (LEA); animals slaughtered weighing $1325 \mathrm{~g}$ presented higher LEAH, LEAL, and LEA than animals slaughtered weighing $625 \mathrm{~g}$. There was no difference between the other treatments. Also, there was no difference between treatments for fillet yield (Table 2).

\subsection{Physical-chemical characteristics and sensory analysis}

The results of the physical characteristics are shown in Table 3. We observed treatments effect on the $\mathrm{pH}$ of thawed fillets: there was a significant difference between the highest and the lowest slaughter weight, with $\mathrm{pH}$ values of 6.53 and $6.30 \mathrm{~g}$, respectively.

There was a significant treatment effect on shear force, drip loss and thawing loss. The lowest shear force was observed in fillets of fish slaughtered weighing $665 \mathrm{~g}$. Regarding drip loss and thawing loss, fish slaughtered at $1325 \mathrm{~g}$ presented the highest values. There was no difference for drip and thawing loss between the other treatments.

There was no treatment effect on color parameters (Table 3 ) and on the chemical composition of Nile tilapia fillets (Table 4).

Table 2

Morphometric measurements and fillet yield of Nile tilapia slaughtered with different weights.

\begin{tabular}{lllll}
\hline \multicolumn{5}{l}{ Slaughter weight } \\
\hline & $665 \mathrm{~g}$ & $1000 \mathrm{~g}$ & $1325 \mathrm{~g}$ & P-value \\
\hline $\mathrm{TL}^{\dagger}$ & $32.6 \pm 0.2^{\mathrm{c}}$ & $37.3 \pm 0.36^{\mathrm{b}}$ & $41.4 \pm 0.82^{\mathrm{a}}$ & 0.0001 \\
$\mathrm{SL}$ & $27.6 \pm 0.2^{\mathrm{c}}$ & $31.5 \pm 0.36^{\mathrm{b}}$ & $34.1 \pm 0.45^{\mathrm{a}}$ & 0.0001 \\
$\mathrm{HL}$ & $7.9 \pm 0.05^{\mathrm{c}}$ & $8.8 \pm 0.09^{\mathrm{b}}$ & $9.7 \pm 0.10^{\mathrm{a}}$ & 0.0001 \\
$\mathrm{BW}$ & $4.5 \pm 0.05^{\mathrm{c}}$ & $5.1 \pm 0.05^{\mathrm{b}}$ & $5.3 \pm 0.06^{\mathrm{a}}$ & 0.0001 \\
$\mathrm{BH}$ & $9.8 \pm 0.09^{\mathrm{c}}$ & $11.2 \pm 0.13^{\mathrm{b}}$ & $12.6 \pm 0.14^{\mathrm{a}}$ & 0.0001 \\
$\mathrm{LEAH}$ & $1.8 \pm 0.06^{\mathrm{b}}$ & $2.07 \pm 0.061^{\mathrm{ab}}$ & $2.1 \pm 0.084^{\mathrm{a}}$ & 0.0090 \\
LEAL & $7.4 \pm 0.15^{\mathrm{b}}$ & $7.9 \pm 0.23^{\mathrm{ab}}$ & $8.4 \pm 0.27^{\mathrm{a}}$ & 0.0190 \\
LEA & $8.5 \pm 0.4^{\mathrm{b}}$ & $11.3 \pm 0.63^{\mathrm{a}}$ & $11.7 \pm 0.62^{\mathrm{a}}$ & 0.0001 \\
FW & $192.8 \pm 5.5^{\mathrm{c}}$ & $290.3 \pm 10.51^{\mathrm{b}}$ & $377.06 \pm 14.4^{\mathrm{a}}$ & 0.0001 \\
FH & $8.2 \pm 0.16^{\mathrm{c}}$ & $9.4 \pm 0.21^{\mathrm{b}}$ & $10.3 \pm 0.21^{\mathrm{a}}$ & 0.0001 \\
FL & $19.4 \pm 0.27^{\mathrm{c}}$ & $22.1 \pm 0.35^{\mathrm{b}}$ & $23.7 \pm 0.27^{\mathrm{a}}$ & 0.0001 \\
FY & $28.9 \pm 0.36$ & $28.7 \pm 0.43$ & $28.2 \pm 0.64$ & 0.6469 \\
\hline
\end{tabular}

a,b,c Different letters in the same row represent significant difference by the Tukey test $(P<.05)$.

$\uparrow$ TL- Total Length (cm); SL- Standard Length (cm); HL- Head Length (cm); BW- Body Width $(\mathrm{cm})$; BH- Body Height $(\mathrm{cm})$; LEAH- Loin Eye Area Height (cm); LEAL- Loin Eye Area Length (cm); LEA- Loin Eye Area $\left(\mathrm{cm}^{2}\right)$; FW- Fillet Weight (g); FH- Fillet Height (cm); FL- Fillet Length (cm); FY- Fillet Yield (\%). 
Table 3

Physical characteristics of fillets of Nile tilapia slaughtered with different weights.

\begin{tabular}{|c|c|c|c|c|}
\hline \multicolumn{5}{|c|}{ Slaughter weight } \\
\hline & $665 \mathrm{~g}$ & $1000 \mathrm{~g}$ & $1325 \mathrm{~g}$ & P-value \\
\hline $\mathrm{pHFF}^{\dagger}$ & $6.75 \pm 0.04$ & $6.78 \pm 0.03$ & $6.71 \pm 0.04$ & 0.5854 \\
\hline pHTF & $6.30 \pm 0.07^{b}$ & $6.43 \pm 0.03^{\mathrm{ab}}$ & $6.53 \pm 0.03^{\mathrm{a}}$ & 0.0142 \\
\hline \multicolumn{5}{|l|}{ White fibers } \\
\hline $\mathrm{L}^{*}$ & $41.55 \pm 0.81$ & $41.61 \pm 0.98$ & $41.42 \pm 1.11$ & 0.8467 \\
\hline$a^{*}$ & $2.38 \pm 0.33$ & $1.68 \pm 0.23$ & $2.77 \pm 0.42$ & 0.09935 \\
\hline$b^{*}$ & $17.79 \pm 0.45$ & $17.1 \pm 0.44$ & $18.40 \pm 0.61$ & 0.35325 \\
\hline \multicolumn{5}{|l|}{ Red fibers } \\
\hline$L^{*}$ & $35.95 \pm 0.9$ & $38.06 \pm 1.22$ & $36.95 \pm 1.25$ & 0.45385 \\
\hline$a^{*}$ & $11.03 \pm 0.78$ & $9.71 \pm 1$ & $10.19 \pm 1.13$ & 0.6477 \\
\hline$b^{*}$ & $21.11 \pm 0.45$ & $20.34 \pm 0.58$ & $20.31 \pm 0.72$ & 0.4483 \\
\hline $\begin{array}{c}\text { Shear force } \\
\text { (Kgf) }\end{array}$ & $1.85 \pm 0.23^{\mathrm{c}}$ & $3.92 \pm 0.23^{\mathrm{a}}$ & $3.08 \pm 0.23^{b}$ & $<0.0001$ \\
\hline Drip loss (\%) & $3.86 \pm 0.27^{\mathrm{b}}$ & $6.43 \pm 0.43^{\mathrm{a}}$ & $6.73 \pm 0.30^{\mathrm{a}}$ & $<0.0001$ \\
\hline $\begin{array}{l}\text { Thawing loss } \\
\text { (\%) }\end{array}$ & $3.7 \pm 0.32^{b}$ & $4.5 \pm 0.45^{\mathrm{ab}}$ & $5.5 \pm 0.41^{a}$ & 0.0132 \\
\hline
\end{tabular}

a,b,c Different letters in the same row represent significant difference by the Tukey test $(\mathrm{P}<.05)$.

$\uparrow$ pHFF -pH Fresh Fillet; pHTF- pH Thawing Fillet; L*- luminosity, a* - redgreen component, and $\mathrm{b}^{*}$-yellow-blue component.

Table 4

Chemical composition of fillets of Nile tilapia slaughtered with different weights.

\begin{tabular}{lllll}
\hline \multicolumn{1}{l}{ Slaughter weight } & \multicolumn{3}{l}{} \\
\hline & $665 \mathrm{~g}$ & $1000 \mathrm{~g}$ & $1325 \mathrm{~g}$ & $P$ \\
\hline Protein (\%) & $20.2 \pm 0.36$ & $20.3 \pm 0.218$ & $19.9 \pm 0.27$ & 0.6607 \\
Moisture (\%) & $75.5 \pm 0.49$ & $74.1 \pm 0.68$ & $74.3 \pm 0.63$ & 0.2005 \\
Dry matter (\%) & $24.4 \pm 0.49$ & $25.8 \pm 0.68$ & $25.6 \pm 0.63$ & 0.2876 \\
Ash (\%) & $2.4 \pm 0.07$ & $2.2 \pm 0.04$ & $2.2 \pm 0.07$ & 0.0808 \\
Total lipid (\%) & $2.38 \pm 0.76$ & $2.19 \pm 0.82$ & $2.71 \pm 0.45$ & 0.4678 \\
\hline
\end{tabular}

Table 5

Sensory analysis of fillets of Nile tilapia slaughtered with different weights.

\begin{tabular}{llllll}
\hline \multicolumn{1}{l}{ Slaughter weight } & \multicolumn{1}{l}{} \\
\hline & $665 \mathrm{~g}$ & $1000 \mathrm{~g}$ & $1325 \mathrm{~g}$ & P-value \\
\hline Juiciness & $6.97 \pm 0.23$ & $7.17 \pm 0.23$ & $7.42 \pm 0.24$ & 0.4094 \\
Texture & $7.47 \pm 0.21$ & $7.54 \pm 0.21$ & $7.80 \pm 0.22$ & 0.5390 \\
Odor & $6.85 \pm 0.28$ & $6.94 \pm 0.28$ & $7.35 \pm 0.29$ & 0.4254 \\
Flavor & $7.59 \pm 0.26^{\mathrm{a}}$ & $7.23 \pm 0.26^{\mathrm{ab}}$ & $6.56 \pm 0.26^{\mathrm{b}}$ & 0.0215 \\
General Appearance & $7.93 \pm 0.24^{\mathrm{a}}$ & $7.58 \pm 0.23^{\mathrm{ab}}$ & $7.11 \pm 0.23^{\mathrm{b}}$ & 0.0532
\end{tabular}

a,b Different letters in the same row represent significant difference by the Tukey test $(\mathrm{P}<.05)$.

Fillets from tilapia slaughtered weighing $665 \mathrm{~g}$ presented the highest flavor and general appearance values, of 7.59 and 7.93 , respectively (Table 5).

\subsection{Gene expression}

We observed the effect of slaughter weight on calpain and calpastatin gene expression (Fig. 1). Fishes slaughtered weighing $665 \mathrm{~g}$ presented higher calpain and lower calpastatin gene expression.

There was no treatment effect on RyR3 gene expression.

\section{Discussion}

Among the main parameters related to the consumer's acceptance of
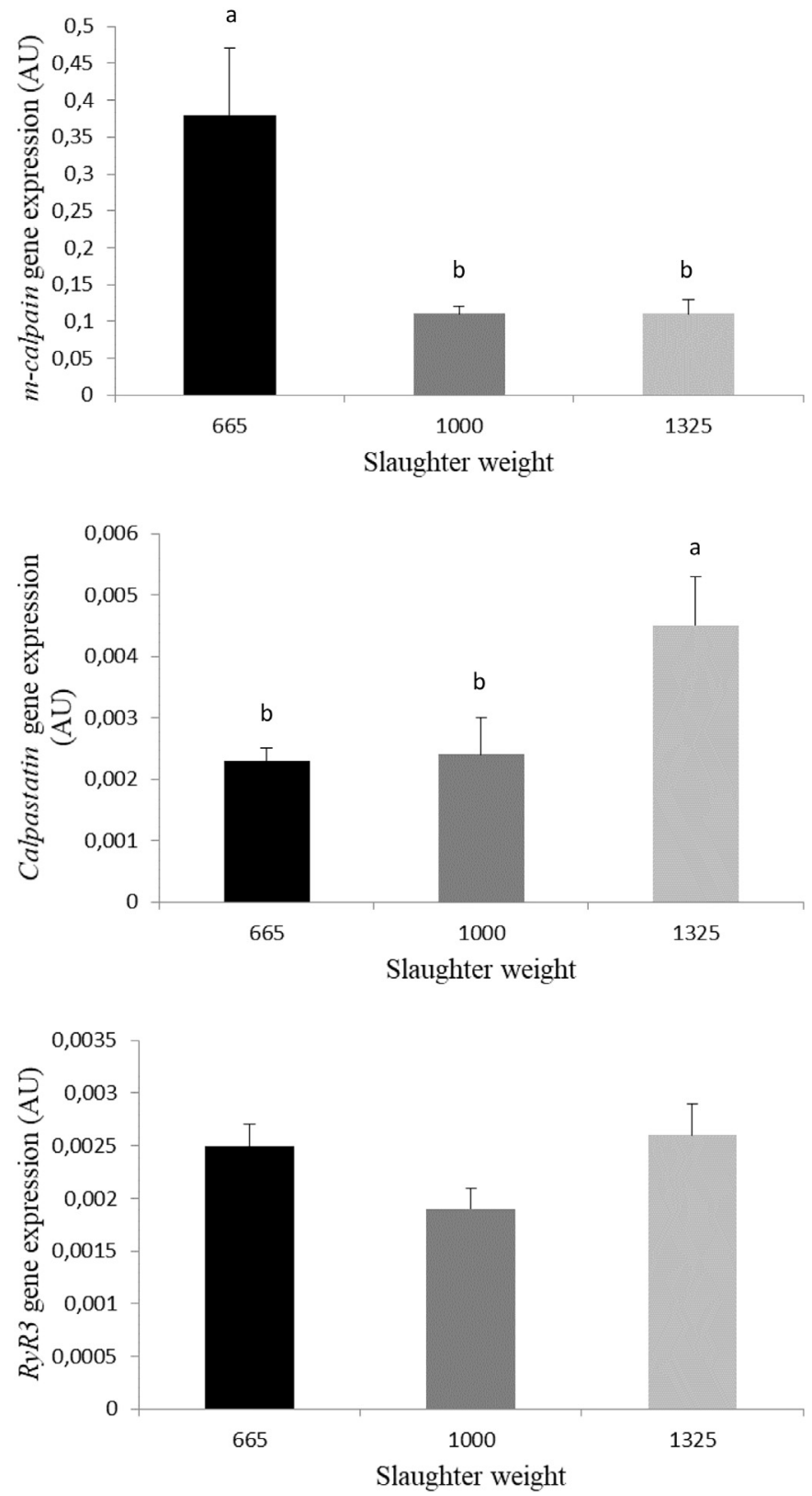

Fig. 1. Effect of slaughter weight on m-calpain (A), calpastatin (B) and ryanodine receptor 3 (RyR3) (C) gene expression on muscle of Nile tilapia. Different letters above the bars indicate significant differences $(\mathrm{P}<.05)$ by the Tukey's test; data are expressed as mean \pm SEM.

the product are the color, general appearance, water retention capacity, texture and juiciness (Fonseca et al., 2013; Listrat et al., 2016), which can generally be influenced by several factors such as blood residue (Roth et al., 2007), fat content and lipid oxidation (Ruff et al., 2002), storage conditions (Guillerm-Regost et al., 2006), and even slaughter conditions (Kristoffersen et al., 2006). Kayan et al. (2015) observed that the slaughter weight of Nile tilapia can influence the characteristics of the meat. Thus, the authors suggest that animals should be slaughtered at different weights depending on the consumer's preference.

In our work, evaluating fillets weighing 665, 1000 or $1325 \mathrm{~g}$, we did not observe a significant effect of slaughter weight on the parameters $\mathrm{L}^{*}, \mathrm{a}^{*}$, and $\mathrm{b}^{*}$ measured in the two regions evaluated in the Nile tilapia fillets, or on the $\mathrm{pH}$ value of the fresh fillets; however, we did observe that the fillets of fish slaughtered with the lowest weight had a lower $\mathrm{pH}$ value after thawing. The $\mathrm{pH}$ of the fish fillet is related to the rigor 
mortis process characterized by the decrease in postmortem $\mathrm{pH}$ associated with the rapid transformation of glycogen into lactic acid (Nakayama et al., 1992). One of the factors that can influence the duration and development of the rigor mortis process is the stress caused at the pre-slaughter moment. The stress is related to the rapid drop in $\mathrm{pH}$ and low ultimate $\mathrm{pH}$ value, which can result in greater water loss, and poorer meat texture (Thiansilakul et al., 2011).

In our study, all animals were kept under the same conditions prior to slaughter, and it was still observed that animals with lower slaughter weight had lower $\mathrm{pH}$ values after thawing, even though there was no difference between the $\mathrm{pH}$ values of the fresh fillets. It is important to note that animals with lower slaughter weight also presented lower water loss due to thawing and dripping, and lower shear force. The texture and water retention capacity are pH-related characteristics (Kristoffersen et al., 2007). It is known that the $\mathrm{pH}$ value after rigor mortis implantation and the rate of drop are fundamental for the processes that transform the muscle into meat. As observed in our work, shortly after slaughter, the $\mathrm{pH}$ value is around 7 . When the $\mathrm{pH}$ value is reduced rapidly, lower water retention capacity associated with increased protein denaturation is observed (Huff-Lonergan and Lonergan, 2005). On the other hand, when there is no reduction in $\mathrm{pH}$ value due to a lack of energy reserves, the meat may have darker coloration accompanied by less tenderness. It is also important to note that the $\mathrm{pH}$ value and the speed taken to reach the ultimate $\mathrm{pH}$ are species-specific.

In addition to $\mathrm{pH}$, many other characteristics may influence water retention capacity, such as the structure of muscle cells and their components as well as genetic factors. Studies have shown that mutations in the ryanodine receptor genes (RyR) and alterations in the activity of these receptors are related to lower capacity in the control of calcium release into the sarcoplasm. This accelerated release of calcium into the cytoplasm allows increased muscle metabolism, which results in lower $\mathrm{pH}$ values in a shorter time and thus lower water retention capacity (reviewed by Huff-Lonergan and Lonergan, 2005). Goes et al. (2015) showed the relationship between the expression of the RyR1 and $R y R 3$ genes and the ability of water retention in animals submitted to different stress conditions prior to slaughter.

In our study, the observed changes in drip and thawing loss were not accompanied by alterations in RyR3 gene expression since there was no effect of slaughter weight on the expression of this gene. Thus, the reduced loss and the lower shear force observed in fillets of fish slaughtered with $665 \mathrm{~g}$ may be related to the higher expression of $\mathrm{m}$ calpain and reduced expression of calpastatin also observed in this group. The postmortem degradation of intermediate filament proteins such as desmin and talin by the action of calpain has been associated with higher water retention capacity (Zhang et al., 2006). Activation of calpains can also resulted in softening of fish muscle (Salem et al., 2004). Calpastatin acts as a regulator of calpain activity, and similar to the observed in mammalians (Casas et al., 2006; Bagatoli et al., 2013; Ropka-Molik et al., 2014), calpastatin has been negatively associated with tenderness traits in fish, as lower calpastatin gene expression is associated with strains that have the slowest growth rate and yielded the softest fillet (Salem et al., 2005). Despite calpain/calpastatin system is the most extensively studied enzyme system involved in meat tenderization (Bhat et al., 2018), the role of these enzymes in fish flesh tenderization remains not fully understood.

The water retention capacity may be related to the chemical characteristics of the meat produced since the loss of water is also related to the loss of muscle proteins (Savage et al., 1990). In our work, despite the results observed for water loss by thawing and dripping, we did not observe any effect of treatments on the chemical composition of fillets. The average protein and moisture content of the treatments was $20 \%$ and $74.6 \%$, respectively. These values are within the range reported by Listrat et al. (2016), who cited values of $20 \%$ and $75 \%$ for protein and moisture, respectively.

The water retention capacity also influences the sensory characteristics of the meat, such as texture and taste (Pelicano et al., 2003).
In the sensory analysis, the significant effect of slaughter weight on juiciness, tenderness and odor was not verified. However, in relation to taste and general acceptance, we observed that higher values were significantly attributed to fillets of fish with lower slaughter weight. This phenomenon was also cited by Johansson et al. (2000) in the sensory analysis of rainbow trout fillets of different aged fish, and may be related to the results of $\mathrm{pH}$, shear force and water loss discussed in our work.

Our results show that slaughter weight may influence important physical and sensory aspects of the quality of Nile tilapia fillets. In general, the results suggest that the slaughter of Nile tilapia with an average weight of $665 \mathrm{~g}$ makes it possible to obtain fillets that serve the consumer market.

\section{Declaration of Competing Interest}

The authors declare no competing financial interests.

\section{Acknowledgements}

This work was supported by the Conselho Nacional de Desenvolvimento Científico e Tecnológico - CNPq, Brazil. This study was financed in part by the Coordenação de Aperfeiçoamento de Pessoal de Nível Superior - Brazil (CAPES) - Finance Code 001.

\section{References}

ABCS, 1973. Método Brasileiro de Classificação de Carcaça. Associação Brasileira de Criadores de Suínos, BR, Estrela.

AOAC, 1998. Official methods of Analysis of AOAC International, 16 ed. Washington, US. Bagatoli, A., Gasparino, E., Soares, M.A.M., Amaral, R.M., Macedo, F.A.F., Voltolini, D.M., Del Vesco, A.P., 2013. Expression of calpastatin and myostatin genes associated with lamb meat quality. GMR. 12, 6168-6175.

Bhat, Z.F., Morton, J.D., Mason, S.L., Bekhit, A.E.D.A., 2018. Role of calpain system in meat tenderness: a review. Food Sci. Human Wellness 7, 196-204.

Bligh, E.G., Dyer, W.J.A., 1959. Rapid method of total lipid extraction and purification. Can. J. Biochem. Physiol. 37, 911-917.

Boscolo, W.R., Feiden, A., 2007. Industrialização de tilápias. GFM Gráfica \& Editora, BR, Toledo.

Casas, E., White, S.N., Wheeler, T.L., Shackelford, S.D., Koohmaraie, M., Riley, D.G., Chase Junior, C.C., Johnson, D.D., Smith, T.P., 2006. Effects of calpastatin and microcalpain markers in beef cattle on tenderness traits. JAS. 84, 520-525.

Castro, P.L., Lewandowski, V., Souza, M.L.R., Coradini, M.F., Alexandre, A.A.C., Sary, C., Ribeiro, R.P., 2017. Effect of different periods of pre-slaughter stress on the quality of the Nile tilapia meat. J. Food Sci. Technol. 37, 52-58.

Cheng, J.H., Sun, D.W., Zeng, X.A., Liu, D., 2015. Recent advances in methods and techniques for freshness quality determination and evaluation of fish and fish fillets: a review. Crit. Rev. Food Sci. Nutr. 55, 1012-1225.

Costa, T.V., Machado, N.J.B., Brasil, R.J.M., Fragata, N.P., 2014. Caracterização físicoquímica e rendimento do filé e resíduos de diferentes espécies de jaraqui (Semaprochilodus spp.). Bol. Inst. Pesca 40, 35-47.

Damez, J.L., Clerjon, S., 2008. Meat quality assessment using biophysical methods related to meat structure. Meat Sci. 80, 132-149.

Department of Fisheries, 2009. Strategy of Tilapia Development 2010-2014. http://www. fisheries.go.th/freshwater/web3/images/download/yutasat.pdf.

FAO, 2011. Fishstat plus: Universal Software for Fishery Statistical Time Series, Version 2.3. FAO Fisheries Department, Fishery Information, Data and Statistical Unit, Rome.

FAO, 2018. Food and Agriculture Organization of the United Nations. The State of World Fisheries and Aquaculture.

Fitzsimmons, K., Martinez-Garcia, R., Gonzalez-Alanis, P., 2011. Why tilapia is becoming the most important food fish on the planet. In: Proceedings of the Ninth International Symposium on Tilapia in Aquaculture, pp. 9-18.

Fonseca, G.G., Cavenaghi-Altemio, A.D., Silva, M.F., Arcanjo, V., Sanjinez-Argandoña, E.J., 2013. Influence of treatments in the quality of Nile tilapia (Oreochromis niloticus) fillets. Food Sci. Nut. 1, 246-253.

Goes, E.S.R., Lara, J.A.F., Gasparino, E., Del Vesco, A.P., Goes, M.D., Filho, L.A., Ribeiro, R.P., 2015. Pre-slaughter stress affects ryanodine receptor protein gene expression and the water-holding capacity in fillets of the Nile Tilapia. PLOS. 10, 1-14.

Guillerm-Regost, C., Haugen, T., Nortvedt, R., Carlehöug, M., Lunestad, B.T., Kiessling, A., Rørár, A.M.B., 2006. Quality characterization of farmed Atlantic halibut during ice storage. J. Food Sci. 71, 83-90.

Horcada, A., Beriain, M.J., Purroy, A., Lizaso, G., Chasco, J., 1998. Effect of sex on meat quality of Spanish lamb breeds (Lacha and Rasa Aragonesa). JAS. 67, 541-547.

Huff-Lonergan, E., Lonergan, S.M., 2005. Mechanisms of water-holding capacity of meat: the role of post-mortem biochemical and structural changes. Meat Sci. 71, 194-204.

Huff-Lonergan, E., Parrish, F.C., Robson, R.M., 1995. Effects of postmortem aging time, animal age, and sex on degradation of titin and nebulin in bovine longissimus muscle. 
JAS. 73, 1064-1073.

Johansson, L., Kiessling, A., Kiessling, K.H., Berglund, L., 2000, Effects of altered ration levels on sensory characteristics,lipid content and fatty acid composition of rainbow trout (Oncorhynchus mykiss). Food Qual. Prefer. 11, 247-254.

Kayan, A., Boontanb, I., Jaturssitha, S., Wicke, M., Kreuzer, M., 2015. Effect of slaughter weight on meat quality of Nile Tilapia (Oreochromis Niloticus). Agric. Agric. Sci. Procedia. 5, 159-163.

Kristoffersen, S., Tobiassen, T., Esaiassen, M., Olsson, G.B., Godvik, L.A., Seppola, M.A., Olsen, R.L., 2006. Effects of pre-rigor filleting on quality aspects of Atlantic cod (Gadus morhua L.). Aquiculture R. 37, 1556-1564.

Kristoffersen, S., Vang, B., Larsen, R., Olsen, R.L., 2007. Pre-rigor filleting and drip loss from fillets of farmed Atlantic cod (Gadus morhua L.). Aquiculture R. 38, 1721-1731.

Kubitza, F., 2000. Tilápia: Tecnologia e Planejamento na produção de Comercial. Fernando Kubitza, Jundiaí, São Paulo.

Listrat, A., Lebret, B., Louveau, I., Astruc, T., Bonnet, M., Lefaucheur, L., Picard, B., Bugeon, J., 2016. How muscle structure and composition influence meat and flesh quality. Sci. World J. https://doi.org/10.1155/2016/3182746.

Livak, K.J., Schmittgen, T.D., 2001. Analysis of relative gene expression data using realtime quantitative PCR and the 2 (-Delta Delta C(T)). Method. Methods. 25, 402-408.

Minolta, K., 1998. Precise Color Communication - Color Control from Perception to Instrumentation. Minolta Co, JPN, Japan.

Mohamed, F.A., Khogali, F.A., Mohamed, A.H., Deng, O.O., Mohammed, A.A., 2016. Body weight characteristics and chemical composition of Nile tilapia Oreochromis niloticus collected from three different Sudanese dam. Int. J. Fish Aquat. 4, 507-510.

Nakayama, T., Da-Jia, L., Ooi, A., 1992. Tension changes of stresses and unstressed carp muscle isometric rigor contraction and resolution. Nippon Suisan Gakkaishi 58, $1517-1522$.

Pelicano, E.R.L., Souza, P.A., Souza, H.B.A., Oba, A., Nokus, E.A., Kodawara, L.M., Lima, T.M.A., 2003. Effect of difference probiotics on broiler carcass and meat quality. Braz. J. Poultry Sci. 5, 207-214.

Pires, A.V., Pedreira, M.M., Pereira, I.G., Fonseca Junior, A., Araújo, C.V., Silva, L.H.S. 2011. Predição do rendimento e do peso do filé de tilápia do nilo. Acta Sci. 33, 315-319.
Ramos, M.E., Gomide, L.A.M., 2007. Fundamentos e metodologias. UFV, BR, Viçosa. Rodrigues, S., Teixeira, A., 2009. Effect of sex and carcass weight on sensory quality of goat meat of Cabrito Transmontano. JAS 87, 711-715.

Ropka-Molik, K., Bereta, A., Tyra, M., Różycki, M., Piórkowska, K., Szyndler-Nędza, M., Szmatoła, T., 2014. Association of calpastatin gene polymorphisms and meat quality traits in pig. Meat Sci. 97, 143-150.

Roth, B., Schelvis-Smit, R., Stien, L.H., Foss, A., Norwedt, R., Imsland, A., 2007. Exsanguination of turbot and the effect on fillet quality measured mechanically, by sensory evaluation, and with computer vision. JSF. 72, 525-531.

Ruff, N., Fitzgerald, R.D., Cross, T.F., Teurtrie, G., Kerry, J.P., 2002. Slaughtering methodand dietary alpha-tocopheryl acetate supplementation affect rigormortis and filletshelf-life of turbot Scophthalmus maximus L. Aquaculture R. 33, 703-714.

Rutten, M.J.M., Bovenhuis, H., Komen, H., 2005. Genetic parameters for fillet traits and body measurements in Nile tilapia (Oreochromis niloticus L.). Aquaculture. 246, $125-132$.

Salem, M., Brett Kenney, P., Killefer, J., Nath, J., 2004. Isolation and characterization of calpains from rainbow trout muscle and their role in texture development. J. Muscle Foods 15, 245-255.

Salem, M., Yao, J., Rexroad, C.E., Brett Kenney, P., Semmens, K., Killefer, J., Nath, J., 2005. Characterization of calpastatin gene in fish: Its potential role in muscle growth and fillet quality. Compar. Biochem. Physiol. B 141, 488-497.

Savage, A.W.J., Warriss, P.D., Jolley, P.D., 1990. The amount and composition of the proteins in drip from stored pig meat. Meat Sci. 27, 289-303.

Souza, M.L.R., Maranhão, T.C.F., 2001. Rendimento de carcaça, filé e subprodutos da filetagem da tilápia do Nilo, Oreochromis niloticus (L), em função do peso corporal Acta Sci. 23, 897-901.

Teixeira, A., Matos, S., Rodrigues, S., Delfa, R., Cadavez, V., 2006. In vivo estimation of lamb carcass composition by real-time ultrasonography. Meat Sci. 74, 289-295.

Thiansilakul, Y., Benjakul, S., Richards, M.P., 2011. Effect of myoglobin from eastern little tuna muscle on lipid oxidation of washed Asian seabass mince at different $\mathrm{pH}$ conditions. JFS. 76, 242-249.

Zhang, W.G., Lonergan, S.M., Huff-Lonergan, E., 2006. Contribution of postmortem changes of integrin, desmin and $\mu$-calpain to variation in water holding capacity of pork. Meat Sci. 74, 578-585. 